\title{
BETTING ON CANADA: THE IMMIGRATION TRAJECTORIES OF MEXICAN PROFESSIONALS AS INTERNATIONAL STUDENTS
}

\author{
by \\ Claudia Iveth Suarez Zamora, BA, Universidad del Valle de México, 2005 \\ A Major Research Paper \\ presented to Ryerson University \\ in partial fulfillment of the requirements for the degree of \\ Master of Arts \\ in the program of \\ Immigration and Settlement Studies
}

Toronto, Ontario, Canada, 2019

(C) Claudia Iveth Suarez Zamora, 2019 


\section{AUTHOR'S DECLARATION FOR ELECTRONIC SUBMISSION OF A MRP}

I hereby declare that I am the sole author of this MRP. This is a true copy of the MRP, including any required final revisions.

I authorize Ryerson University to lend this MRP to other institutions or individuals for the purpose of scholarly research.

I further authorize Ryerson University to reproduce this MRP by photocopying or by other means, in total or in part, at the request of other institutions or individuals for the purpose of scholarly research.

I understand that my MRP may be made electronically available to the public.

Claudia Iveth Suarez Zamora 


\title{
BETTING ON CANADA: THE IMMIGRATION TRAJECTORIES OF MEXICAN PROFESSIONALS AS INTERNATIONAL STUDENTS
}

\author{
Claudia Iveth Suarez Zamora \\ Master of Arts 2019 \\ Immigration and Settlement Studies \\ Ryerson University
}

\begin{abstract}
Canada has positioned itself as a destination for thousands of international students from all over the world. Arguably, by offering a relatively affordable education, and an inclusive society. Over the past two decades, the number of international students to Canada has not just increased, but also become more diverse by places of birth, age, marital status, education, and prior occupation. Even though many international students come to Canada when they are single young adults, some arrive with their families leaving behind professional careers back home. Using a qualitative approach, this research explores the motivations that prompt Mexican professionals to come to Canada as international students with their families. The research findings demonstrate that high levels of insecurity in Mexico was the number one push factor that motivated participants to make the decision to immigrate. Furthermore, for many this represents a significant financial investment that can require sacrifices both before and after immigrating.
\end{abstract}

Key words: Mexico; international students; insecurity; immigration; professionals 


\section{ACKNOWLEDGEMENTS}

First and foremost, I want to express my gratitude to my husband, Luke Brodie and my son, Ian. Your love, patience and motivation were the fuel that kept me going and helped me complete my goal. Thank you, Luke, for always believing in me and for your incredible and constant support throughout this year, especially during the writing process of this MRP. I could not have done it without you.

I would like to thank my supervisor, Dr. Sutama Ghosh, for her time and her honest and useful feedback during this MRP process. I would also like to thank my second reader, Dr. Lu Wang, for her valuable input.

Thank you to my friend, Christine, for her kind words of motivation and her advice. I am also grateful to my family and friends in Canada and Mexico for all their support and encouraging words.

Finally, I would like to thank the participants in this research for their time and for sharing their experiences with me. 


\section{TABLE OF CONTENTS}

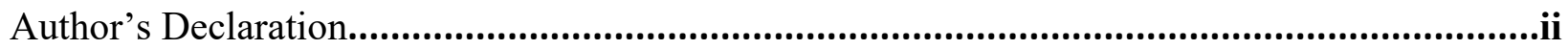

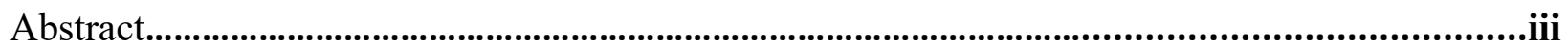

Acknowledgements..................................................................................................................................iv

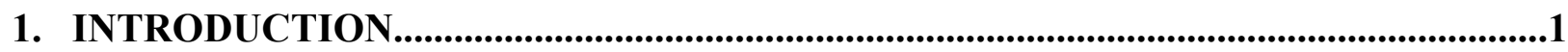

2. LITERATURE REVIEW .............................................................................................................4

2.1. Migration Intentions

2.1.1. Motivation of IS to study abroad

2.1.2. Importance of recruitment of IS to Canada

2.2. Settlement

2.2.1. Employment

2.2.2. Housing

2.2.3. Pedagogical

2.2.4. Transition to permanent residence

2.3. State of knowledge on Mexican immigration to Canada

2.3.1. Temporary workers

2.3.2. Refugee claimants

2.3.3. International students

2.4. Appraisal and the conceptual approach

3. RESEARCH DESIGN AND METHODS

3.1. Research design

3.2. Setting and sample

3.3. Data collection

3.4. Data analysis

3.5. Ethical considerations

3.6. Positionality

4. RESEARCH FINDINGS

4.1. Demographics

4.2. Motivations

4.2.1. Insecurity in Mexico

4.2.2. Gender based insecurity

4.2.3. Other factors

4.3. Canada as a destination for IS

4.3.1. IS application process

4.3.2. Obtaining permanent residence

4.3.3. Quality of life

4.3.4. Family network

4.4. Choosing post-secondary institutions in Canada

4.4.1. Path to Permanent Residence

4.4.2. Cost of the programs

4.4.3. Career advancement 
4.5. Financial investment

4.5.1. Savings

4.5.2. Loans and Scholarships

4.5.3. Employment

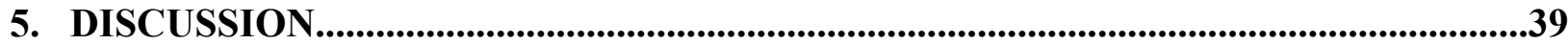

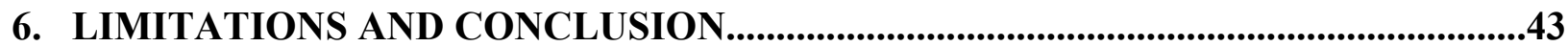

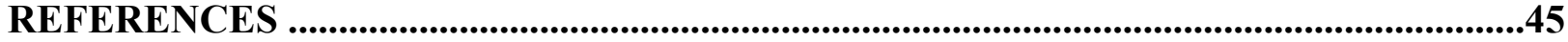




\section{INTRODUCTION}

Since the early 1970s, Canada has positioned itself as a destination for thousands of international students (IS) from all over the world. By offering arguably, a relatively affordable education, and an inclusive society the number of IS to Canada has not just increased, but they have also become more diverse in the recent years by place of birth, age, marital status, education, and prior occupation.

In Canada, IS are seen by the government as "ideal immigrants." This is because they enter the country at a relatively young age, they are proficient in English and/or French, they attain Canadian education credentials which are an important asset for Canadian employers, and develop an understanding of the Canadian labour market, that it is believed will aid their adaptation process (Alboim, 2011; Arthur \& Flynn, 2011; Dam, Chan, \& Wayland, 2015; GatesGasse, 2010; Lu \& Hou, 2015; Scott, Desai, Trilokekar \& El Marsi, 2015). The recruitment of IS has become part of a strategy for Canada to attract highly skilled immigrants and in so doing to continue with its nation-building prospect, where immigrants are valued for the human capital that they bring to the country (Arthur \& Flynn, 2011; Chatterjee, 2015; She \& Wotherspoon, 2013).

The Government of Canada (2019a) definition of an international student is "a temporary resident who is legally authorized to study in Canada on a temporary basis". According to statistics from the Government of Canada (2018), in 2017 Canada received approximately 492,533 IS. The main sending countries were China with 139,998 students, India with 123,535 students, and South Korea with 22,977 students. The recruitment of IS in Canada has seen high growth of 33.8\% in the period between 2014 and 2017 (Government of Canada, 2018) which coincides with the creation of the "International Education Strategy" implemented by the federal government in 2014, of which the main objective was to attract IS throughout the marketing of 
Canadian education (Chatterjee, 2015; Anderson, 2015; Scott et al., 2015). For Canada, the recruitment of IS is a lucrative business, generating approximately $\$ 8$ billion annually from tuition fees and living expenses from IS (CBIE, 2018).

Over the past two decades, the number of IS to Canada has not just increased, but also become more diverse by places of birth, age, marital status, education, and prior occupation. For instance, IS to Canada not only come from China and India but also from several other Asian, African, and South American countries. even though many IS come to Canada when they are single young adults, some also arrive with their families leaving behind professional carriers back home. Despite such diversity within IS, however, the main focus of existing academic research has been on IS from China. Furthermore, the main emphasis of the academic literature has been on IS' mobility, especially the reasons they choose to study abroad as well as the importance to Canada of IS recruitment, and challenges to settlement such as employment, housing, pedagogical issues faced by students in the educational institutions, and their path to permanent residence. As a result, there is a dearth of literature on IS who come to Canada with their families (partner and/or children). With more than two thousand IS attending post-secondary institutions, currently, Mexico is the 12th largest sending country of IS to Canada. Despite the increasing number of the Mexican born population in Canada ${ }^{1}$, there is a growing gap in the literature studying this group, more specifically Mexican IS to Canada that arrive with their families. Keeping this knowledge gap in mind, the main purpose of this research is to understand the factors that drive Mexican professionals (and their families) to make the decision to immigrate to Canada as IS.

\footnotetext{
${ }^{1}$ According to the 2016 census, the total number of Mexican born immigrants in Canada exceeds 80,000 (Statistics Canada, 2017). This includes permanent residents, temporary workers, refugee claimants, and IS.
} 
The following two interrelated research questions will be addressed in this Major Research Paper (MRP): 1.- What are the motivations of Mexican professionals to seek post-secondary education in Canada? and 2.- What are the financial implications that IS from Mexico face when making the decision to come to Canada?

This paper begins with a critical review of the relevant literature on IS to Canada, focussing specifically on the push-pull factors that may have led them to choose Canada as the destination. The literature review will also assess current research that deals with the different challenges that IS face during their studies in Canadian post-secondary institutions. In order to put the research in context, an overview on the state of knowledge on immigration from Mexico to Canada is provided. At the end of the literature review, the conceptual approach for this research is presented. The chapter on research design and methods outlines the rationale for choosing this specific study group, data collection procedures, and my positionality as an "insider" of the community. Thereafter, the research findings and discussion from the interviews are presented, and finally, the conclusion and the limitations of the study are addressed. 


\section{LITERATURE REVIEW}

This literature review looks into the research that has been done pertaining to IS and their trajectories to immigrate to Canada. The scope of the review includes peer-reviewed journals, published scholarly book chapters, dissertations and theses, as well as papers from organizations in the immigration and international education fields and government research publications. The search terms that helped identify the literature used included international students, immigration, motivations, mobility, recruitment, challenges, and various combinations thereof.

An important global trend that emerges through different research on the topic of IS is the number of scholarly articles that are dedicated to IS from East Asia and South Asia. In the context of Canada, this is understandable due to the large number of IS who come from countries such as China, India and South Korea (Government of Canada, 2018). The growing literature on IS to Canada can be classified into at least two broad themes: Migration and Settlement.

Under the migration theme, the main emphasis of the academic literature has been on IS' mobility, especially the reasons they choose to study abroad as well as the importance to Canada of IS recruitment. Literature has shown how Canada is in competition with other countries such as Australia, the United Kingdom, and the United States to attract IS and the economic boost they can bring. Under the settlement theme, the main focus has been on challenges to settlement such as employment, housing, pedagogical issues faced by students in the educational institutions, and their path to permanent residence. This literature review also looks into the state of knowledge on Mexican immigrants to Canada, and the academic research that has been done pertaining to the migratory flows between Mexico and Canada. 


\subsection{Migration Intentions}

\subsubsection{Motivation of IS to study abroad}

The academic literature that has emerged in the past several years regarding the mobility of IS has looked to identify the reasons that motivate IS to study abroad on a global scale and has in its majority followed the trajectories of IS to western countries such as Australia, the United Kingdom and the United States using a push-pull model (Wilkins, Balakrishnan, \& Huisman, 2012). This model focuses on studying the factors that affect migration decisions, (De Hass, \& Miller, 2014, p. 28). The first scholars that used the push-pull approach to examine the factors that influence their decision to seek higher education overseas were McMahon (1992) and Mazzarol \& Soutar (2002), who conducted quantitative and qualitative research on IS from developed countries to the United States (McMahon,1992) and to Australia from Indonesia, Taiwan, China and India (Mazzarol \& Soutar, 2002).

Several scholars including Abubakar, Shanka, \& Muuka (2010); Binsardi \& Ekwulugo, (2003); Bodycott, (2009); Maringe \& Carter, (2007); Mavroudi, \& Warren (2013); Mazzarol \& Soutar, (2002); McMahon, (1992); Shanka, Quintal, \& Taylor, (2005); Yang, Volet, \& Mansfield, (2018) agree that the most common pull factors globally include economic links between the home and source country, reputation of the educational institutions, quality of education, quality of life, family recommendations, knowledge of host country, recognition of credentials, employment opportunities, geographical location, cost of living, and tuition fees. The same scholars discuss the decision to leave the home country (push factors) which are related to the current state of their home country politically and economically, intentions to migrate permanently, and quality of education at the source country's institutions.

Within the Canadian context, the academic literature related to the motivations of IS to choose Canada as a destination for their studies has shared similarities in relation to the pull 
factors that are important in the decision-making process for IS. According to the literature, Canada is seen as a destination of choice for IS due to the relatively easier immigration process in obtaining student permits in comparison with the US (Chen, 2007), better employment opportunities (Arthur \& Flynn, 2011), quality of Canadian higher education (Li \& Tierney, 2013), and family connections in the host country (Wintre, Kandasamy, Chavoshi, \& Wright, 2015).

Canada is also seen as an option to immigrate permanently due to its immigration policy regarding permanent residence for IS after graduation (Chen, 2017). Several authors point out the advantage that Canada has within the international community as being perceived as a multicultural, tolerant, and safe country (Chen 2007; Cudmore, 2005; Parra-Sandoval, 2014; Zhukovskyi \& Simak, 2015). Finally, the financial support that these IS sometimes receive through scholarships from Canada is also a pull factor (Parra-Sandoval, 2014).

Wilkins et al. (2012) noted that most scholars had mainly focused on the pull factors that make a destination country attractive for IS, while the push factors that motivated IS to leave their home country were approached in a more general and broader way. There are also limitations under the push-pull model, principally because student characteristics such as age, gender, level of post-secondary education, and personal preferences are not taken into consideration, therefore the motivations and decision-making process to choose a destination country are mainly seen through an external perspective (Chen, 2007; Wilkins et al., 2012).

\subsubsection{Importance of recruitment of IS to Canada}

The research that has studied the recruitment processes of IS has shown that key host countries such as Australia, Canada, and the UK have implemented immigration policies that facilitate the entrance and the future possibility of becoming permanent residents as a strategy to 
attract and retain IS. This is in order to compete in the global market of international education and has played a significant role into the determinants of student mobility (Beine, Noël, \& Ragot, 2014; Sá \& Sabzalieva, 2018; She \& Wotherspoon, 2013; Tremblay, 2005).

In the case of Canada, several scholars have studied the reasons why the recruitment of IS is important to the country. One of the main reasons that has come up in the academic literature is the benefits to the economy as IS represent a profitable business to Canada (Anderson, 2015; Cudmore 2005; Guo, \& Guo, 2017; Knight 2008). In this regard, CBIE (2018) reports that IS in Canada are an $\$ 8$ billion industry, in which revenues come from both tuition fees and living expenses from IS. Statistics Canada (2018) released a report stating that average Canadian tuition fees for IS in the 2018/19 school year were $\$ 27,159$ for undergraduate and $\$ 16,497$ for graduate students. Domestic students pay considerably less at $\$ 6,838$ and $\$ 7,086$ annually at the undergraduate and graduate levels respectfully ${ }^{2}$.

On top of the high tuition fees, students from other countries wishing to study in Canada must demonstrate the ability to cover their living expenses. This is required by Immigration Refugees and Citizenship Canada (IRCC). The annual amounts are approximately $\$ 10,000$ for the main applicant, $\$ 4,000$ for the first accompanying family member, and $\$ 3,000$ each for any other accompanying family members (IRCC, 2017a).

The research has also shown that the recruitment of IS has become part of a strategy for Canada to attract highly skilled immigrants and in so doing to continue with its nation-building prospect, where immigrants are valued for the human capital that they bring to the country (Arthur \& Flynn, 2011; Chatterjee, 2015; She \& Wotherspoon, 2013). Furthermore, IS are seen as "ideal immigrants", as they have the advantage of entering the country at a young age, a level

\footnotetext{
${ }^{2}$ Average tuition fees of full time students enrolled in publicly funded universities and degree granting colleges in Canada
} 
of proficiency in English and/or French, they attain Canadian education credentials which are an important asset for Canadian employers, and an understanding of the Canadian labour market, that it is believed will help with their adaptation process (Alboim, 2011; Arthur \& Flynn, 2011; Dam, Chan, \& Wayland, 2015; Gates-Gasse, 2010; Lu \& Hou, 2015; Scott, Desai, Trilokekar \& El Marsi, 2015). The successful recruitment of IS has also been related to the demand of younger people to have access to higher education that cannot be met in their home countries (Altbach \& Knight, 2007).

Finally, several scholars have pointed out that the importance of the recruitment of IS to Canada lead to the creation of the "International Education Strategy" implemented by the federal government in 2014, whose main objective was to attract IS throughout the marketing of Canadian education, targeting post-secondary students in important markets such as Brazil, China, Mexico, Vietnam, among others (Chatterjee, 2015; Anderson, 2015; Scott et al., 2015). According to the Government of Canada (2014), its original target aimed to recruit 450,000 IS by 2022, however, this number was surpassed in 2017 with 492,533 IS in the country (Government of Canada, 2018). In 2019 the Canadian government announced a $\$ 147.9$ million budget to continue their support to the International Education Strategy and to invest in activities that promote Canada as a main destination for IS (Government of Canada, 2019b).

\subsection{Settlement}

Canada's immigration strategies to attract IS have had a positive outcome and has seen an increase in the recruitment of IS that look for higher education outside their home country. However, as the number of IS rise, so do their needs for settlement services and challenges they face upon arrival to the country, during the course of their education, and through their immigration process when looking to immigrate permanently. 
As Roach (2011) pointed out, the responsibility of providing these settlement services have been put upon the educational institutions, as IS are not eligible to access most settlement services that non-profit organizations provide for newcomers which could help with their integration and adaptation in Canada. This has added more challenges for IS, as in some cases educational institutions do not have enough resources to provide the support they need. The research on challenges for IS indicates that they are principally related to employment, housing, and adaptation which includes the domain of the host country language, pedagogical needs as well as mental health issues, and the transition to permanent residence.

\subsubsection{Employment}

In relation to barriers regarding employment, the empirical research has shown that even though IS are entitled to work legally while attending school, there are some restrictions that hinder their potential opportunities to find full time employment, such as the number of hours that they are allowed to work while completing their studies (Bond, S., \& Canadian Bureau for International Education, 2007). The importance of finding full time work for IS is not only related to financial stability but also to help them obtain Canadian experience in their professional field, which has been pointed out as another barrier when looking for work (Nunes, \& Arthur, 2013; Scott et al., 2015).

IS have also pointed out the feeling of discrimination that they get from employers due to their temporary immigration status, the fact that English is often not their first language, as well as the lack of recognition of their international work experience (Nunes, \& Arthur, 2013; Scott et al., 2015). Network connections have also been mentioned by IS as an important barrier for employment (Arthur, \& Flynn, 2011; Nunes, \& Arthur, 2013). As Scott et al. (2015) found in their research, one of the common feelings among IS was that the lack of professional network 
connections was one of the factors that put them at a disadvantage in the job market when looking for jobs related to their field of study.

\subsubsection{Housing}

The research shows the barriers that IS face when looking for housing in Canada are mostly related to affordability, as IS spend more of their living expenses on accommodation which can lead to them living in inadequate housing. Some IS have also expressed that they are pushed to live off campus, because of the higher costs of the residences for them. This is problematic because in some cases IS have to consider not only an extra cost due to transportation to school, but also isolation as they might not feel included in the student life that happens when living on campus (Calder, Ritchter, Mao, Burns, Mogale, \& Danko, 2016; McEwan, \& Teixeira, 2012; Zhou \& Zhang, 2014).

IS also have problems when it comes to looking for a place to live, as they might not be familiar with the housing market, the rules and regulations in the new city, and the lack of knowledge they have about their rights as tenants, as well as the sources of information they need to navigate the system more effectively, as they mostly rely on information provided by their friends and family (Calder et al., 2016; McEwan \& Teixeira, 2012).

Another challenge related to housing for IS found by McEwan \& Teixeira (2012) is that many IS face discrimination by landlords on the grounds of racism and/or sexism, as well as unfair rent increases, conditional time for leasing, and portraying IS as unreliable because of their age and condition as students. The authors pointed out that even though measures have been put in place by the city (in this case Kelowna, BC) to protect tenants, landlords have continued with these discriminatory practices. 


\subsubsection{Pedagogical}

IS face several academic barriers at Canadian post-secondary institutions. One of the main challenges has been related to language as IS can face difficulties communicating with their professors and classmates, doing schoolwork (including presentations and writing assignments), and comprehension of the materials in their non-native language. (Ge, Brown, \& Durst, 2019; Scott et al., 2016; Zhang \& Zhou, 2010).

The research on this topic has found that IS did not have enough academic support on campus or in some cases were not aware of the programs that their institutions offer. This is in addition to them having limited resources (Scott et al., 2015). Scholars have also found that cultural differences in the education system in comparison with their home country can play a role in the challenges faced by IS in academia (Ge et al., 2019; Scott et al., 2015).

\subsubsection{Transition to permanent residence}

Research has shown that when transitioning to permanent residence, IS have faced barriers related to the immigration process as they do not have the necessary support from the schools. This support could be for extending or obtaining a work permit or staying permanently in the country. They have to navigate the system, which in some cases can be confusing because of all the required criteria that they must comply with through IRCC (Arthur \& Flynn, 2011).

Another barrier found by scholars is the disadvantage that IS have when applying through the Express Entry ${ }^{3}$ program, for several reasons. First of all because IS are in competition with

\footnotetext{
${ }^{3}$ The Express Entry System gives IS the opportunity to apply for permanent residency after concluding their studies. The program functions by awarding a number of points (1,200 in total) for different factors, including human capital factors such as age, level of education, official languages proficiency, Canadian work experience; spouse or common-law partner factors, including level of education, official language proficiency and Canadian work experience; skilled transferable factors, education, foreign work experience, certificate of qualification; and additional points for a brother or sister living in Canada and French language skills, post-secondary education in Canada, arranged employment, provincial nomination (IRCC, 2017b
} 
the pool of skilled workers that are also applying to receive an invitation under this program, as only the ones with higher points are invited to apply (Dam et al., 2018; Wang, 2018).

Furthermore, under the Express Entry program the majority of IS are not able to apply for permanent residency right after concluding their studies, as they have to demonstrate that they have completed at least 12 months of full time work in their field after graduation, and with this

apply under the Canadian experience category (Scott et al., 2015; Wang, 2018).

When a recent graduate does not have enough work experience, human capital factors such as education in Canada, language skills, and age are the only way in which they can obtain a higher number of points. However, this might not be enough for them to receive an invitation to apply as work experience and job offers are the most important factors that are considered under this program. Moreover, age can be a problem for those who have finished a masters or a $\mathrm{PhD}$ program, as they lose five points every year after turning 29 years old (Dam et al., 2018).

\subsection{State of knowledge on Mexican immigration to Canada}

Immigration of Mexicans to Canada has increased in the last two decades. In 1994, the North American Free Trade Agreement (NAFTA) was signed. This agreement not only facilitated trade and changed the view of North America as a common partner - politically, culturally, and economically; it also allowed Mexican professionals' movement to Canada (Young, 2018 p. 37). NAFTA made it easier for Mexican nationals to enter Canada not only to do business, but also to work in high skilled jobs. Clerical roles and manual labour were also included in NAFTA, however, these work permits did not mean that participants were entitled to apply for permanent residency (Mueller, 2005).

According to the last census conducted by Statistics Canada (2017) in 2016, the number of Mexican born population residing in the country reached 80,585 . Out of this number 18,660 
are landed immigrants who became permanent residents between 2011 and 2016. Despite the increasing number of the Mexican born population in Canada, there is a growing gap in the literature following statistical information and immigration patterns of Mexicans residing temporarily and permanently in the country. Temporary residents in Canada, include temporary workers, refugee claimants, and IS. Some scholars have researched the statistical flows of Mexican nationals to Canada and the impact that this has had on the relationship between these two countries (George, 2008; Mueller, 2005).

\subsubsection{Temporary Workers}

Most of the body of research regarding immigration from Mexico to Canada has focused in the Seasonal Agricultural Workers Program (SAWP). Several scholars have studied in depth the socio-political and economic aspects of the migratory trajectories of workers participating under the SAWP as well as the multiple challenges they face in both Mexico and Canada (Basok, 2002; Binford, 2006; Brem 2006; Preibisch \& Encalada, 2010; Preibisch \& Hermoso Santamaria, 2006).

Mexico has been a producer of workers to Canada, specifically agricultural labour. Since the Seasonal Agricultural Workers Program (SAWP) was established in 1974 (Brem, 2006). The Government of Canada (2018) reported that in 2017 Canada received 27,224 workers from Mexico, under the Temporary Foreign Worker Program, making Mexico the number one sending country under this category. According to the Ministry of Labour in Mexico, out of this number, 25,344 where agricultural workers that arrived in Canada under the SAWP (STPS, 2018). 


\subsubsection{Refugee Claimants}

In 2008 it was reported that the number of refugee claims from Mexican nationals was 9,554, making Mexico the number one source of country of asylum claimants (Government of Canada, 2018). These numbers led to the implementation of the visa in 2009 and later to the inclusion of Mexico to the list of Designated Countries of Origin. These changes in immigration policy towards Mexico, attracted the interest of several scholars who looked into the humanitarian aspects of the immigration of Mexicans to Canada and the correlation to the insecurity that prevails in Mexico as a push factor (Bhuyan, Vargas, \& Píntín-Perez, 2016; Rotman \& Marshall, 2016; Villegas, 2013). In 2017, the number of Mexicans seeking asylum in Canada was 1,518 putting Mexico at number eight of the top countries of origin for refugee claimants (Government of Canada, 2018).

\subsubsection{International students}

According to the Government of Canada (2018) in 2017, the number of Mexicans coming to the country to study reached 6,885 , Statistics Canada (2019) reported that out of this number 2,361 came to study in public post-secondary institutions, with 1,650 students enrolled in universities and 711 in colleges. This has positioned Mexico 12th on the list of countries of origin for IS. The increase of IS from Mexico has been growing steadily in the past 10 years (Table 1).

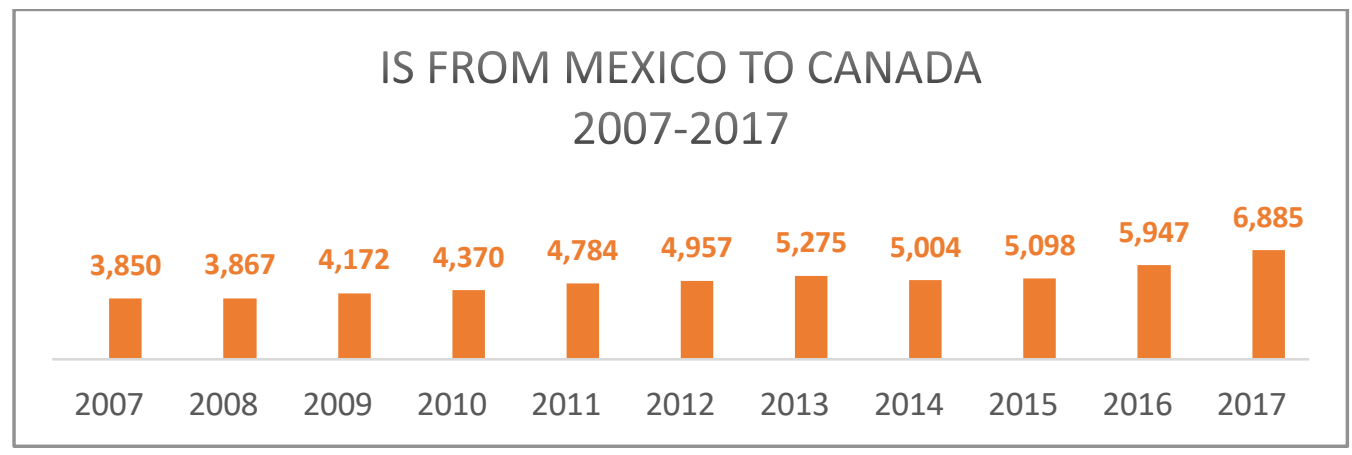

Table 1. Government of Canada, 2018 
Despite the growing numbers of IS from Mexico to Canada, there is an important lack of academic literature studying this sector of the population. Only one article was found by ParraSandoval (2014), who in her exploratory research analyzed the migratory movement of Venezuelan and Mexican nationals to Canada to pursue graduate education, as well as the main factors that influenced the decision of the participants in choosing Canada as a destination. This study also found a correlation between the insecurity in Mexico and the decision of IS to immigrate to Canada.

In the global context, some of the research that has been done pertaining the mobility flows of IS from Mexico has focused on the scholarships that Mexican professionals have received to study abroad and how this has developed into the so called brain drain, that has left Mexico without important human capital (Aupetit, 2006; Felix, 2003; Rodriguez Gomez, 2009; Sieglin, \& Zúñiga, 2010). Other research has outlined the importance that the academic formation of the students has when choosing a destination country, especially for graduate students (Gérard \& Maldonado 2008; Lopez Ramirez, 2017), as well as their experiences when studying abroad (Rehaag Tobey, 2008).

\subsection{Appraisal and the conceptual approach}

A review of the relevant literature demonstrates that, the reasons why IS come to Canada may be more complex than simply a push-pull situation. One of the main gaps that was found in the literature regarding the mobility of IS was that even though these studies explore the reasons IS are drawn to choose a country to immigrate (pull factors), more research needs to be done in regards to the role that the socio-political, cultural, and economic reasons in the home country play (push factors), as well as the personal characteristics of IS that have influenced their decision to immigrate to Canada. 
This literature review also helps to understand the connection that exists between the strategies that Canada uses to recruit IS through the marketing of international education and the policy surrounding the immigration paths of IS. However, it is important to point out how this can affect the expectations that IS have when they use this as an immigration strategy to become permanent residents.

Also, making the decision to voluntarily move to another country is an exercise that perhaps goes hand in hand with the rational thinking approach, as individuals, in this case, IS from Mexico, have to consider all the factors that will have a greater benefit for them (Todaro, 1976; Haug, 2008). There is also a correlation with human capital in the process of making the rational decision to immigrate, as one has to consider the job opportunities that will be available for them once arriving at the receiving country (Sjaastad, 1962; Haug, 2008).

In view of the previous research findings, it seems that theoretically and empirically, both human capital and rational choice theories can perhaps shed some light in analysing the reasons why IS come to Canada. Within the framework of immigration and settlement studies, Human capital theory can be defined as "the more skills and education that an individual has, the more likely they are to succeed in the labour market and to be contributing members of society" (Bragg \& Wong, 2015 p49).

In addition to human capital theory, the main idea of rational choice theory may help to conceptualise this research project as it states that "individuals are seen as resourceful actors who select from sets of alternatives, while constraints and opportunity structures impose restrictions on their choice. A cost benefit approach underlies the decision-making process." (Haug, 2008 p586). Therefore, the rational choice theory can be used to explain the factors that influence how potential IS from Mexico choose Canada as the destination country. 
This research will answer the following research questions:

1.- What are the motivations of Mexican professionals to seek post-secondary education in Canada?

2.- What are the financial implications that IS from Mexico face when making the decision to come to Canada?

The goal of this study is to close the gap in regard to the literature pertaining Mexican IS that come to Canada with their families and understands the motivations and the financial implications behind this decision. 


\section{RESEARCH DESIGN AND METHODS}

\subsection{Research Design}

This research adopted a qualitative approach in which data was gathered through face to face intense interviews with participants in the form of open-ended and semi-structured questions. According to Charmaz (2006, p.25), "the in-depth nature of an intensive interview fosters eliciting each participant's interpretation of his or her experience." This type of interview approach also focuses on guiding the participant into reflecting on these experiences and encourages the interviewer to be more empathetic and to engage in exploring further details of these stories. Validating the informant's points and observing the reactions that occur during the interview process are important aspects that must be taken into consideration when conducting intensive interviews (Charmaz, 2006).

The research design for this study was based on grounded theory. This is a qualitative research method in which data is collected and analyzed in a flexible and systematic way to construct theories based on the data that has been obtained (Charmaz, 2006). Upon considering the views of the IS from Mexico participating in this study, I was able to build on the general theory, simultaneously collecting and analyzing data. As explained by Charmaz (2006 p.2), "by adopting grounded theory methods, you can direct, manage, and streamline your data collection

and, moreover, construct an original analysis of your data." Based on this design inquiry, the data that I obtained from participants' experiences helped to compare the social patterns that push professionals from Mexico to move to Canada as IS and invest their money in their studies.

\subsection{Setting and Sample}

This research looked into the experiences of IS from Mexico who live in the province of Ontario. The participants for this study were required to meet the following demographic criteria: 
1) Mexican citizens 2) currently enrolled as international post-secondary students in universities and colleges in Ontario 3) have a post-secondary degree or certificate from another country, including Mexico 4) have immigrated to Canada as an IS with their families (partner or/and children).

The recruitment of participants and interviews were done between March and June 2019 and three different recruitment methods were used. First, through social media by posting messages in two different Facebook groups with Mexican membership. One group is called Mexicanas en Toronto Oficial, which has 1,133 members to date who reside in different parts of Ontario and are women. The other group is called Profesionistas Mexicanos en Toronto y GTA and this group has 1,325 members who reside in Toronto and the GTA. Members are professionals with different career paths, and membership is not restricted by gender. All intended publications in these groups were approved in advance by their corresponding administrator. To protect participants' identity, I disabled the comment feature on the posts related to this study and I asked potential participants to contact me directly by private Facebook message or email.

In addition to the above, an email explaining the research study and the recruitment criteria was sent out to the Mexican community organizations such as: Exatec Ontario Professional Network, Mexican Professionals Group of Canada (MEXPROCAN), and Confederación de Estudiantes de Posgrado e Investigadores Mexicanos en Canadá (CEIMEXCAN), all of which had contact information available online to the public. The rationale for choosing these organizations was that their member base are Mexicans who reside in Ontario, that have already completed a post-secondary degree and have professional work experience. 
Snowball sampling, which is described as "a technique for gathering research subjects through the identification of an initial subject who is used to provide the names of other actors" (Atkinson \& Flint, p.1044), was used in order to obtain a heterogeneous group of informants. This is why in both Facebook and email messages I provided my contact information to allow these organizations to forward this message to interested participants that fit the criteria and for them to voluntarily contact me. As a result of this recruitment strategy, one of the participants of these study was recruited via the Facebook group Mexicanas en Toronto Oficial, three participants were recruited through the Facebook group Profesionistas Mexicanos in Toronto and the GTA, and one participant was recruited through snowball sampling and contacted me directly by email.

For this study, I recruited five participants that were between the ages of 29 and 46 years old. I was able to find participants that were enrolled in both universities and colleges in Ontario. This helped to look at the different trajectories in their immigration processes and to have a comparative framework between the different levels of post-secondary education in Canada. Two of the participants were enrolled in master's programs, two were completing their certificates in public Colleges, one participant was previously enrolled in a private college before switching to a public College, and one participant was doing his second diploma at a private College. All participants were attending educational institutions in Toronto and the GTA.

\subsection{Data Collection}

This research adopted a qualitative approach, primary data was gathered through face to face interviews with participants consisting of 15 open-ended and semi-structured questions divided by themes in the interview guide. Participants had the option to answer the questions in English or Spanish. However, all five participants chose to have the interviews conducted in 
Spanish. The reasoning for giving the option to conduct the interviews in Spanish is that this was seen as a potential strength as it allowed for open and culturally comfortable dialogue, reminiscent of more natural conversation, and therefore increasing the trustworthiness of the study.

The interviews were audio-recorded on a digital recording device in order to make a written transcription and use the responses for my data. The interviews were conducted in a private room at a public library and at a study room at Ryerson University, maintaining aural and visual privacy of the participants. Each interview lasted between 30 and 70 minutes.

Demographic information such as gender and age were captured in the interview guide, as well as time, date, and location of the interview to support the data analysis of this research.

\subsection{Data Analysis}

Grounded Theory was the method of analysis that I used in this study to explain the reasons why Mexican professionals make the decision to move to Canada along with their families and invest large amounts of money to pursue post-secondary education. Using grounded theory as a method of analysis helped not only to describe and explore this phenomenon but also explain it, as Birks and Mills (2015, p.16-17) point out "the strategies used in data collection and analysis result in the generation of theory that explicates a phenomenon from the perspective and context of those who experience it." The process of analysis consisted of categorization of the collected data, in which I identified words that were important individually and as a group, which then were labeled by categories. This was done during the process of collection and analysis, in which "data is coded before more data is collected or generated and the process of analysis repeated." (Birks \& Mills, 2015 p.11). The tool that I used to analyze the data in my study was 
manual coding. The decision to use manual coding was based on the number of participants in my study, which made manual coding more manageable (Birks \& Mills, 2015).

\subsection{Ethical Considerations}

One of the requirements of participants in this study was that they were requested to disclose information about their families which could include some potentially traumatic events that had to do with their decision to immigrate to Canada. To mitigate this, participants were provided with informed consent in writing via email prior to the interview which outlined any potential risks. Participants were invited to email me any questions regarding consent or their participation in advance. Furthermore, participants were reminded of the possibility of pausing for a break, withdrawing from the interview or asking questions at any time. A hard-copy of the consent form in both English and Spanish was available to the informants to sign prior to the commencement of the interview.

I was the only person to have access to the audio-recorded version of the interview. The audio recordings of the interviews were erased immediately after being transcribed. Transcription of the audio recordings was done only by me. Transcriptions were stored on the Ryerson Google Drive which is secure and encrypted. Quotes of the transcribed interviews were translated by me into English for the purpose of this MRP.

In order to maintain confidentiality, the name of the participants and the name of the academic institution where they are currently studying were not revealed in this study. The interview was written up using pseudonyms rather than their real names to link interview subjects to the data. Signed consent forms and all non-electronic data (i.e. field notes) were stored separately in a locked security box only accessible to myself. Following the completion of the study, all data will be kept for one year and will be deleted and shredded right after. The reason 
for collecting email addresses was for the purpose of recruitment, communicating with the informants, and sending them the consent forms and making arrangements for the location and time of the interviews. E-mail correspondence between the investigator and each participant was confidential and will be deleted following the submission of the investigator's MRP.

\subsection{Positionality of the researcher}

In some ways outlined herein, I am an insider of the group I studied because I share some of the same characteristics of the interview participants. More specifically, according to Asselin (2003), this means I share an identity, language, and experiential base with the study participants. I am of Mexican descent and speak fluent Spanish. This provided me with the ability to interview participants in their native language, thereby developing rapport more quickly. My personal experience as an immigrant in Canada helped me empathize with the stories of the participants and share some of the challenges that newcomers face in Canada. Like the study participants, I also completed my undergraduate degree in Mexico and self-identify as middle-class. While I am not an IS, I am familiar with the struggles of friends who have immigrated to Canada as IS. I have worked for both the Mexican government in Canada in a limited settlement capacity and for non-profit settlement agencies in the GTA as a settlement counselor. This experience gave me first-hand knowledge of some of the issues newcomers to Canada seek help with. Finally, while

my motivation to immigrate to Canada was not related to insecurity in Mexico, I am familiar with the safety issues prevalent in the country, having been of target of robberies myself while living there. As a woman, I am also familiar with the harassment several female participants described as being the norm in Mexico. All these factors could feed into a bias when conducting the interviews, so I mitigated this by asking open questions and not suggesting potential answers. 


\section{RESEARCH FINDINGS}

This section describes the research findings that emerged from the data collected during the face to face interviews. First, the demographics of the participants will be presented to give the reader background information about the group. Then, the findings will be divided into four main themes: 1) Motivations to immigrate, 2) Canada as a destination for IS, 3) Selection factors of post-secondary institutions in Canada, and 4) Financial investment. Each of these themes will be broken down into subsections.

\subsection{Demographics of the participants}

For this study, five semi-structured interviews were conducted with IS from Mexico. In Table 2, the socio-demographic composition of the participants is presented.

Table 2: Socio-Demography of Interview Participants

\begin{tabular}{|c|c|c|c|c|c|c|}
\hline Pseudonym & Gender & Age & $\begin{array}{c}\text { Marital } \\
\text { Status }\end{array}$ & $\begin{array}{c}\text { Type of } \\
\text { post- } \\
\text { secondary } \\
\text { institution } \\
\text { in Canada }\end{array}$ & $\begin{array}{c}\text { Field } \\
\text { of Studies } \\
\text { in Canada }\end{array}$ & $\begin{array}{c}\text { Undergraduate } \\
\text { degree in Mexico }\end{array}$ \\
\hline Laura & Female & 46 & Married & University & $\begin{array}{c}\text { Executive } \\
\text { MBA }\end{array}$ & Marketing \\
\hline Martha & Female & 32 & Married & University & MBA & Engineering \\
\hline Susana & Female & 34 & Married & $\begin{array}{c}\text { Public } \\
\text { College }\end{array}$ & $\begin{array}{c}\text { Business } \\
\text { Administration }\end{array}$ & Psychology \\
\hline Kena & Female & 39 & Married & $\begin{array}{c}\text { Public } \\
\text { College }\end{array}$ & $\begin{array}{c}\text { Finance } \\
\text { Diploma }\end{array}$ & Accounting \\
\hline Leonardo & Male & 29 & Married & $\begin{array}{c}\text { Private } \\
\text { College }\end{array}$ & $\begin{array}{c}\text { Computerized } \\
\text { Accounting } \\
\text { Diploma }\end{array}$ & Administration \\
\hline
\end{tabular}


As shown in Table 2, each participant was given a pseudonym. At the time of the interviews, all participants were married and had brought their partners with them to Canada. One of the five participants have children. Out of the five participants, one was male and four were females. The participant's ages, as shown in the table, ranged from 29 to 46 years. Each participant had completed an undergraduate degree in Mexico - the table indicates their field of studies in their undergraduate programs. The participants arrived in Canada between 2017 and 2018. Four of the five participants attended post-secondary institutions in Toronto and one in the GTA. Two participants attended university and were enrolled in master's programs. Another two participants were enrolled in certificate programs at public colleges and of these two, one had previously been enrolled at a private college. The fourth participant was enrolled at a private college. The fields in which they studied in Canada are indicated in the table. All the participants in this study had been professionals in Mexico with work experience that ranged between 2 and 20 years. Most had worked in their field of studies, were well established in their careers, and still working before moving to Canada. All participants identified their socioeconomic status as middle class, which they said allowed them to be economically stable in Mexico.

\subsection{Motivations to immigrate}

\subsubsection{Insecurity in Mexico}

When asked about the reasons that influenced the decision to immigrate, all five of the participants stated that high levels of insecurity in Mexico was the number one factor that made them want to leave the country. As Leonardo explains:

... I think the number one reason that pushed us to leave Mexico, would be safety. Unfortunately, Mexico is not doing well in terms of safety in the area where we were living [North Metropolitan area of Mexico City]. When we decided to come [to Canada], a wave of violence that we had not experienced in such a tangible and visible way began, 
of kidnappings, extortion, murders, so I think it was the main reason that pushed us to leave [Mexico].

All of the participants talked about how the increased violence had affected their everyday lives and that a constant feeling of fear had been normalized in Mexico. Participants mentioned that they felt that it was up to them to protect themselves from violence, specifically robberies and kidnappings, by trying to keep a low profile, not buying expensive cars, trying not to go out late at night, and driving instead of taking public transit. Leonardo, who had been robbed a couple of times while riding public transit on his way to work, gave an example of how even having a cellphone can make someone a target for criminals, and in some cases a person can be killed if they resist the robbery. The participants reported that these situations limited their sense of freedom as they were constantly in a state of alert and uncertainty since their safety was at risk on a daily basis. In this context, all five participants shared different experiences with insecurity in Mexico at different levels, either that had happened to them personally or to a close family member or friend.

Laura described how her husband was robbed at gunpoint in his car while stuck in traffic in Mexico City. Even though she feels lucky that she has not experienced the violence directly, Kena mentioned that her husband had been robbed several times over the past few years and how her colleagues and friends have also fallen victim to delinquency. Martha shared her personal story about her experience with insecurity in Mexico:

When I was 19 years old, they tried to kidnap me at [name of university]. That was a watershed [in my life] because my parents wanted me to leave Mexico City ... It was an event that marked my life in many ways, ever since I said [to myself] - I don't want to live like that [with fear]. Today 12 almost 13 years have passed, and I have gone to psychologists and everything and I have overcome part of the trauma, but there are things that stay there, and I think you can't move forward because the country we live in [Mexico] doesn't allow it. 
Susana shared a situation that happened to a close family member. This affected her family and was a major factor that influenced her decision to leave Mexico. As she explains:

One of the main reasons for which I told him [my husband] that I wanted to return here [to Canada] to live, to settle here, was that before we came, my cousin was killed and that had a big impact on my family. I told him [my husband] - I don't want to live that-. I was scared to go out; everybody was. The family structure fell apart, so I didn't want...I didn't want to continue living the uncertainty that something would happen to me or to my husband, [and] if we had children that they were going to grow up in a place where they would have to be inside [the house] all the time, I wouldn't like that for my children

A common factor that emerged in the interviews was that the decision to immigrate was made as a family unit and was seen as a benefit for the whole family. As Susana mentioned, her decision was not only based on her direct or indirect experiences with insecurity in Mexico, but also how this had affected her partner which led to them deciding together to immigrate. In the case of Laura, her seven-year-old son was considered in the decision-making process due to a constant fear that something could happen to him or their family. Laura explains:

[Mexico] right now is very, very, very unsafe, especially for children. I have a seven-yearold boy and I wanted my son to be free, to play in the streets and in Mexico you can no longer do that, in Mexico all the activities for children are indoors... I talked to my husband and we decided to go to a safer country, especially for him [my son].

Three of the participants that did not have children, also took their future family plans (children) into account as a reason to immigrate as they did not want them to experience the insecurity that is currently affecting Mexico. Susana explains:

[The reason to migrate] I think that in the first place I will put safety. We don't have children yet, but I would like them to grow up in a place where they can enjoy their childhood as I did. I used to go out and play in the streets and there was no problem. I used to go and play in the park with my friends and I was ok. I would like my children to have a peaceful life.

For Leonardo, insecurity also restricted his ability to advance in his professional projects. He wanted to open his own business in Mexico, however, he felt like this was too risky as he 
believed it would have made him a target for extortion from criminal groups, or worse - to be kidnapped. He realized that the insecurity factor in the country would always be a barrier for him and his wife to carry out their life projects.

\subsubsection{Gender based insecurity}

Gender based insecurity came up several times during the interviews. Most of the participants explained how being a woman increased their feelings of fear related to insecurity in Mexico. Several female participants recounted experiences of being harassed in the streets while walking alone or even while accompanied by another family member. They had to change the way they dress to avoid being harassed, even though this did not guarantee their safety. Martha recalled her experience the first time she walked into the university in Mexico City where she was going to study. She was catcalled by the male students, which was seen as a normal action towards women inside the school. Even before the attempted kidnapping she suffered, she tried to dress in loose clothing in order to avoid any attention inside the university. However, she still felt that even when she took all the measures that she thought would have kept her safe, she was still a target, which left her feeling like she would never enjoy her freedom while in Mexico.

In the perspective of Leonardo, the only male in the study, he also saw how gender-based insecurity affected his wife, as they both worried every time she finished work late. He would pick her up at work as they knew that taking a taxi or any other form of public transit would have been too risky for her.

\subsubsection{Other factors}

Only two other factors that were not related to security were mentioned among participants as secondary reasons that contributed to the decision to leave Mexico. One of them 
was an environmental factor, related to the earthquake that happened in Mexico City on September 19, 2017. Kena explained how this was a terrifying and traumatizing event for her husband and knowing the high probabilities of another earthquake could happen again, as Mexico City is located in a high-risk earthquake zone, it was better for them to relocate outside Mexico in order to alleviate his fear.

Susana mentioned that she believed that society in Mexico has become more aggressive and disrespectful, which was another reason for her immigrate. She felt that in recent years that people in Mexico were more selfish and did not care if their actions would affect you, that they did not think about the others. This was an emotional situation to her as even though she stated that she missed her family and friends a lot, she did not expect this situation to improve in Mexico in the near future.

\subsection{Canada as a destination for IS}

\subsubsection{IS application process}

Most participants mentioned that the motivation to choose Canada specifically for their studies was based on the immigration process, including potential advantages of being an IS. These include being able to bring their family while studying, obtaining an open work permit for their spouses, and the possibility of obtaining PR after their studies. Three of the participants heard about these possibilities through friends and acquaintances. Laura mentioned that she learned about fairs promoting immigration to Canada and other countries through different programs. However, she got the information about immigrating as IS through a friend from Mexico that was living in Canada. Martha said her cousin had studied in Canada, and because of her, she knew about the possibility of getting a three-year work permit and the later getting permanent residence. 
Susana explains how in one of her visits to Canada she heard about immigrating as an IS through acquaintances, and how this prompted the decision to come to Canada.

The wife of my husband's friend told us - you know I studied at this school [private college] and this school is going to allow you to work and study and after that you are going to get a co-op and then you will be able to apply for permanent residence- So we [my husband and I] thought - let's do it, it will be two years, we want to stay in Canada, and this is going to help us to find a better job, we can do it this way [as IS].

In the case of Kena, she and her husband attended an event about immigration programs at the Canadian Embassy in Mexico which led them to do more research about other programs offered by Canada. She explains:

About three years ago we went to an event about immigration at the Canadian Embassy, there we found out about the Express Entry program. When we started to evaluate all the options that this program had, we realized that there was also the possibility of coming as IS and based on the time that you were studying, they would give you a work permit and after that you could apply for permanent residence.

Leonardo had little information about immigrating as an IS before coming to Canada, as he initially had come with his wife as a tourist with the purpose of enrolling in an ESL program for three months. After they finished their ESL program, they decided they wanted to stay in Canada, so they consulted a lawyer to evaluate options to remain in the country legally. The lawyer explained the option of attending a private college and leveraging that to get a work permit not only for him, but also for his wife.

Several participants mentioned that applying as an IS was a faster way to immigrate to Canada than getting their permanent residence while still in Mexico through the Express Entry program. According to the information provided by the participants, most of them stated that their application process to get their study permit, took between two and four weeks after they submitted all their paperwork to IRCC. For Laura, the timeframe was important because she wanted to leave Mexico as soon as possible due to insecurity. She explains: 
The fastest way [to immigrate] is as an IS because the only thing you need is the letter of acceptance from the school and to submit all the papers [to IRCC] and they [IRCC] are supposed to get back to you in two weeks, even though in my case it took a month, however this was better than waiting six or eight months [through Express Entry]. [Time] Was important to us because we wanted to leave [Mexico] as soon as possible due to the insecurity.

\subsubsection{Obtaining Permanent Residence}

One common theme that emerged from this research was the main goal of all the participants, in the long run, was to obtain permanent residence. Most participants believed that being IS not only offered a faster way to immigrate temporarily to the country, but also the opportunity to apply for permanent residence in the future. Several participants knew that they could apply for permanent residency while in Mexico through the Express Entry program, however, in doing their research they realized they did not have enough points to be invited to apply under this program.

Laura said that even though she had the professional experience and the level of English required, her age was an issue that would not help her to get an invitation to apply through this

program. She believed that getting an education in Canada would give her more points that might counteract the age factor. Kena experienced a similar situation. She explained that after doing an online evaluation to see if they would qualify for the Express Entry program, she and her husband realized that they did not have enough points. She explained:

The main objective is to try to obtain permanent residence. That is why we decided that I was going to study. One of us had to study because the main issue we had with Express Entry was that we did not have the points that they give you when you study and work in Canada $[\ldots]$

For Leonardo, being an IS gave his wife time to build Canadian Experience, as she was able to find a full-time job that would give them points for their application through Express 
Entry. This has enabled them to start considering submitting their profile to the IRCC website because they have built upon the qualifications that they had as professionals in Mexico.

\subsubsection{Quality of life}

All five participants indicated that quality of life was an important pull-factor that made Canada a desirable destination for their studies. Participants mentioned a variety of elements within this pull-factor, including safety, reliable transportation, and their perception of Canada as being a tolerant and multicultural country. As Leonardo explains:

I wanted to come to Canada for a long time. I had read articles and watched videos about the quality of life [in Canada], its multiculturalism, safety, the landscapes, the quality of life in general, transportation, all these factors made me decide to immigrate to Canada

All participants talked about how they have already experienced the benefits of the quality of life in Canada as IS, principally related to safety. Participants described feeling free to do things that they would not do in Mexico, such as walking late at night and taking public transit without fear that something would happen to them. In the case of some of the female participants, they mentioned that they were able to wear whatever they want without being harassed in the streets. On a related note, some also talked about how traffic and long commute times in Mexico were affecting their quality of life and how this has changed in Canada. Martha recalled how she used to have a four-hour commute (two-hours each way) everyday due to the traffic and how she did not feel safe taking public transit. She explained:

Here [in Canada] I take the subway and I am not worried about my safety; I would never do that in Mexico. There I don't even take a taxi, maybe an Uber but, I would never go by myself.

Furthermore, several participants discussed already feeling accepted as immigrants in Canada as a contributing factor to the quality of life. This is something they attribute to Canada being a multicultural country and they to them while living here. Several participants also 
explained how they felt that the Canadian society, in general, was more respectful which had a connection of the level of safety the experience here. Susana explained:

Here [In Canada] most people are very patient, and they try not bothering you, they are very concerned about respecting each other and I like that a lot, and it makes me feel very comfortable and safe here [in Canada]

\subsubsection{Family Network in Canada}

Only two participants mentioned having family living in Canada. Leonardo indicated that having family in Toronto was an important factor in his decision to choose Canada as a destination to immigrate. Kena said that her husband has a cousin in the GTA which helped with the decision not only to come to Canada but also choosing the location of the college at which she wanted to study.

\subsection{Choosing post-secondary institutions in Canada}

\subsubsection{Path to Permanent Residence}

Several factors influenced participants' decisions in choosing their post-secondary institution and level of education. For Laura, Kena, and Susana, the main factor they considered was whether their program or institution would make them eligible for a post-graduate work permit which would allow them to pursue permanent residence after their studies. Laura explains:

When I decided to apply [to a program] I applied to three schools with three different programs. First of all, they had to be on the authorized list of schools from the government that will let me work after finishing my studies. I applied to a diploma program at [name of the college], a certificate at [name of the college] and to a master's program.

Laura also said that the first acceptance she received was for a master's program. She had heard that at this specific university there was an immigration program through which she could apply for permanent residence right away after finishing her masters. She saw this as the best 
option as her main objective when immigrating to Canada was to eventually obtain permanent residence.

\subsubsection{Cost of the programs}

Cost was an important consideration for the participants and weighed heavily on their decisions. Susana had initially chosen a program at a private college because of the lower price and because the person who recommended it told her she would be able to work after finishing her studies and get permanent residence. However, she soon realized this was not the case, and ended up switching to a program at a public college. She explained:

[When] I first arrived I was in another program at a private college, it was a private institute [name of the private school], but when I went to the person that was giving us advice about immigration, she said that private colleges don't give you points [for the Express Entry], so we decided to look for a public college [...]

She elaborated that even though this was a more expensive option, she thought this would be more viable and aligned with her future plans of obtaining permanent residence.

For Leonardo, even though he wanted to enroll in a public college for the benefits this would give him not only academically but also in relation to pursuing permanent residence in the future, he decided to enroll at a private college to complete a diploma, as it was the only type of school he could afford. This also gave him and his wife the opportunity to work while he was studying.

\subsubsection{Career advancement}

All the participants mentioned that continuing their studies in Canada would give them the opportunity to learn and be more prepared professionally. Most saw this as a secondary benefit, not a main reason to enroll in the programs. However, for Martha, the main reason to 
choose a master's program was based on the benefits that this would bring her professionally, as she saw this as the next step in her career. She explains:

I was a consultant [in Mexico], [in this field] the more you go up, the more necessary a master's degree becomes. My undergrad was in Mechatronics Engineering, so an MBA made sense because I was not working in my field of studies, I was more focused towards the business part... so I said [to myself] I need an MBA, so I started looking for schools.

Martha also mentioned that her choice of university was based on the reputation of the school as well as the MBA program that she wanted to pursue. She explained that she had applied to two different universities in Toronto and she chose not only the one that accepted her first, but also the one that had a program that aligned with her professional background.

\subsection{Financial Investment}

\subsubsection{Savings}

When I asked participants how they cover the cost of the school as well as their living expenses, all five stated that they have used their savings. As mentioned above, all participants were professionals and had worked in Mexico for several years before moving to Canada. Most mentioned that they considered that they were earning good salaries in Mexico which allowed them to save money and thus finance their studies in Canada. Kena explained how they started saving two and a half years before moving to Canada:

We started saving money two and a half years ago. Every month we saved as much as we could from both our paychecks, we started putting away a big amount of money to put towards school. We made a budget in order to know how much we would need for tuition, rent, food. Based on that we started tightening our belt every month. I even checked Walmart's website in order to have as realistic a budget as possible... 
She added:

We brought all the savings we had, we sold all our furniture, we sold the car that we had in Mexico, this was a big help as [the car] was only two years old. We sold everything we had, and we used all our savings.

Like Kena, all of the other participants mentioned that they sold their cars, and had used all their savings, some of them also use the bonus they received from their jobs. Laura said that she had emptied her bank account in Mexico. Susana also shared that she rented her house in Mexico for approximately $\$ 400$ and how this provides a source of income while in Canada.

All participants indicated that if they would have to go back to Mexico in case they were not able to stay permanently in Canada, that financially speaking they would have to start their lives back home from scratch, with probably zero money in their bank accounts. They felt this was a risk that they were willing to take in return for a better quality of life for them and their families.

\subsubsection{Loans and Scholarships}

Out of the five participants, only Martha relied on loans and scholarships to cover the cost of her education in Canada. She got the loans from two different organizations in Mexico that offer financing for students who had been admitted to graduate programs abroad. She got a scholarship through Mexico's National Council for Science and Technology (CONACYT) as well as a scholarship from the university in Canada where she was accepted. Martha made emphasis on the difficulties that she faced when doing the paperwork with CONACYT to get the scholarship. She mentioned that the bureaucracy and the disorganization that exist within this Mexican organization caused her added stress that made her be absent from work. She also mentioned that her father in Mexico lent her money to cover her living expenses and part of the tuition. 


\subsubsection{Employment}

Most participants mentioned that they were also relying on finding employment upon arrival to Canada to cover some of their living expenses while studying. Several participants thought that given that they have several years of professional experience in Mexico it would be easier for them and their spouses to find jobs in their professional field. Laura explained how this was not the case for her as she faced two significant barriers when looking for jobs in Canada. She said:

It's hard when you can't find a job [in Canada]. You think that you can find a better job, but you can't get it because you don't have Canadian experience, and then you need to get that Canadian experience in order to get a job, it's like a vicious cycle [...]

She added:

The study permit limits you to work 20 hours [per week], so either you work at the university, where you don't have this restriction, or you get an entry level job as an assistant or in retail.

Kena explained the further employment difficulties that her husband faced, even with an open work permit, that were inconsistent with their expectations prior to immigrating:

We thought that having an open work permit was going to be an advantage for my husband, as he could work anywhere without restriction. However, the disadvantage that we faced was that to work in his field [in Canada] he needed certifications which he didn't have $[\ldots]$

For Susana, the recognition of credentials was also an issue when looking for work in her

field. She mentioned that she was a psychologist in Mexico and if she wanted to work in Canada, she not only needed Canadian experience but also to have her credentials recognized. She also mentioned that her husband encountered a similar situation as he had studied law in Mexico. In his case, he would have to go back to school to study Canadian law. She said the only job they 
could find at that time was cleaning bathrooms and that they took this job while they look for something better. 


\section{DISCUSSION}

The intent of this research project was to understand the motivations of Mexican professionals (and their families) to pursue post-secondary education in Canada, and the financial implications this decision has on them. This research answers the following questions: 1.- What are the motivations of Mexican professionals to seek post-secondary education in Canada? 2.What are the financial implications that IS from Mexico face when making the decision to come to Canada?

One of the main findings was that high levels of insecurity in Mexico was the number one push factor that motivated all participants to make the decision to immigrate. When insecurity was described by the participants, they referred to kidnappings, extortions, robberies, and in the case of most of the female participants, gender insecurity in the form of sexual harassment. This study also found that most participants were concerned about the quality of life that they could offer to their present and future children in Mexico if they had decided to stay as they believed the climate of violence and crime would not change in the long run ${ }^{4}$. Even though safety was a push factor mentioned in the study by Parra-Sandoval in relation to the immigration of Mexican IS to Canada, it was not explored in detail through the experiences of participants, as her main focus related to the decision to immigrate to Canada was based on the pull-factor conditions that Canada offers, such as quality of life and security.

Another important finding in this study was the financial investment that IS from Mexico made in order to immigrate to Canada. This finding appears to be new to the existing literature.

\footnotetext{
${ }^{4}$ In October 2015, the UN High Commissioner for Human Rights, visited Mexico and their findings were extremely worrisome as they concluded that the society in this country remained "wracked by high levels of insecurity, disappearances, and killings, continuing harassment of human rights defenders and journalists, violence against women, and terrible abuses of migrants and refugees transiting through the country on their way to the United States.” (Rotman \& Marshall, 2016 p8).
} 
The data shows that most participants used their savings as the main way to finance their studies. This was due to the fact that they were professionals with established careers in their home country, whose socioeconomic status as middle-class helped them allocate resources towards their goal of immigrating to Canada.

The financial implication is that in most cases the money they brought from Mexico would only last for the period of their studies, if even that long, as it was based on the amount that IRCC requires to comply with the application process for IS. Therefore, Mexican IS and their families rely on finding employment during their studies to cover their living expenses in the long run. However, as the literature has shown, IS face challenges when looking for employment due to a variety of barriers, such as lack of Canadian experience, recognition of their credentials and limitations within their work permit (Nunes, \& Arthur, 2013; Scott et al., 2015). These challenges finding employment were also reflected in the data collected from the participants in this study.

The data in this study also demonstrates how the immigration policies implemented by the Canadian government targeting IS were a major determinant for this group to choose Canada as a destination. The majority of the participants in this research made their decision based on the fast and relatively easier to navigate immigration process for IS, the advantage of being able to work legally in the country for both the main applicant and their partners/children, as well as the potential opportunity of obtaining their permanent residence in the future, which for most of them was their main goal. This aligns with the study done by Tremblay (2005 p.197) in which he explains that immigrating as IS could be seen as a "deliberate immigration strategy from the prospective students.”

However, it is important to point out that although these immigration policies acted as a motivation for participants in this study to make their decision to immigrate to Canada, there are 
no guarantees they will be granted permanent residence after finishing their studies, as participants were not fully aware of the barriers that they could face in their transition to permanent residence. As the literature shows, one of the main barriers, since the implementation of the Express Entry system in 2015, is that IS are in direct competition with other high skilled immigrants that also applied trough this immigration stream (Dam et al., 2018; Wang 2018). In reality, the majority of IS are not able to apply for permanent residency right after concluding their studies, which means that their process has now converted into a two-step migration process, in which they have to stay in the country and find a job in their field in order to gain Canadian experience and in so doing gain more points in the Comprehensive Ranking System (CRS) (Wang, 2018, p1066).

Furthermore, the present study shows that the decision-making process of Mexican IS to migrate to Canada was not deliberate, as they did consider the factors that they thought could have a greater benefit for them, being the most important quality of life and better employment opportunities, which is supported by rational choice theory (Todaro, 1976; Haug, 2008). Though, this aligned with my original conceptualization, the findings of this study suggest that the decision of immigrating to Canada for the participants was taken as a family unit for the greater benefit of all family members, contrary to the individualistic framework that rational choice theory suggests.

The relationship between rational choice and human capital theory is also shown in the findings, as most participants based their decision to immigrate on immigration policies for IS that suggest that immigrants in Canada are valued by the human capital that they bring to the country (Wang, 2018). In this regard, most of the participants in the present study considered their own human capital when deciding to immigrate to Canada and the expected outcomes that they considered in their decision-making process, as they were under the impression that their 
professional background, experience and credentials would give them better employment opportunities. Moreover, human capital theory helps to understand how the Canadian immigration laws are written with the goal of attracting "the best and the brightest" and building a country where the "highly skilled" individuals would help the nation grow and compete in the global economy (Gabriel, 2006 p164).

A consideration from a rational choice perspective is whether investing all of one's savings in a journey as an IS without considering a financial safety net is indeed rational. I believe it can be, given that if the participants in this study were to return to Mexico following their studies, the education they received in Canada, combined with their English skills that would have improved as an ancillary benefit of living in an English-speaking country, they would likely be able to find a good job there. This potential phenomenon has human capital tie-ins since the gain in the participants human capital can benefit them regardless of where they choose to live and work after their studies.

Finally, although most of the participants indicated that they felt that this was a risky investment, as they do not have any guarantees of staying permanently in Canada, they were willing to take a chance if this meant that they can improve the quality of their lives. And for the participants that have or want to have children in the future, they believe living in Canada will help them provide a better life for them. 


\section{LIMITATIONS AND CONCLUSION}

The present study is not without limitations. Primarily, the case selection and relatively limited sample size meant that findings are not to be generalized to reflect the wider IS experience in Canada. More specifically, only five participants were interviewed, all with similar demographic profiles. For example, all are from large Mexican cities, identify as middle-class and four of the five participants identify as female. The time constraint of this study impacted the ability to recruit a larger and more generalized diverse sample that would be representative of the broader Mexican population. Time constraints also restricted the sample to only include participants studying in and around Toronto. A final time-related constraint was that these interviews only represented a single point in time within a longer journey, therefore any findings could change depending on the next steps in these participants' journeys and might have been different at the beginnings thereof.

Language was another limitation. Because I speak Spanish, I could interview participants in their first language. At first, I thought this would be a benefit, and in some ways it was, however translating the interviews afterwards was difficult because word-for-word translations do not exist for all of the expressions used. Furthermore, because participants seemed to feel more comfortable sharing in Spanish, this invited them to digress during their answers and go on tangents unrelated to the interview topic.

The experiences of Mexican IS in this study offered an important insight into the push factors that made them take the decision to immigrate to Canada. Their personal accounts with insecurity in Mexico emerged as a determinant of their decision to look for a better future for them and their families, even though if this meant leaving their country and their professional careers. The window of opportunity that they saw throughout the immigration policies that 
Canada offers for IS, was an important pull factor along with the quality of life that the country has.

To put it in a colloquial way, betting on Canada was part of the strategy that IS from Mexico adopted in an effort to provide a better life for themselves and their families. The educational component of this journey was an enabler, not a determinant. If other paths existed with different enablers, these same participants would likely have examined and potentially pursued them with the goal of immigrating permanently to Canada.

Further research with a larger and more heterogeneous sample in this area is necessary to understand the migration patterns, expectations, and outcomes for Mexican nationals who decide to immigrate to Canada to pursue post-secondary education. This could be expanded upon by ensuring the sample represented Mexicans from different parts of the country, from different socioeconomic statuses, and at different levels of study. On the Canadian side, a comparative study of the experiences of IS in different parts of Canada could contribute to the body of knowledge on this topic. From a time standpoint, further study is recommended to follow the journeys of IS from Mexico to learn about how their plans and expectations evolve as they move through each step of the immigration process.

A final recommendation for further study would be to compare the experience of IS from Mexico with those of IS from other countries with similar political situations. Given the finding of the motivation to escape violence in Mexico, much could be learned about the experience of people from elsewhere in the world also looking to study in Canada with the goal of obtaining permanent residence so that they can escape violence in their home countries. 


\section{REFERENCES}

Abubakar, B., Shanka, T., \& Muuka, G. N. (2010). Tertiary education: An investigation of location selection criteria and preferences by international students - the case of two Australian universities. Journal of Marketing for Higher Education, 20(1), 49-68. doi:10.1080/0884124100378805

Alboim, N. (2009). Adjusting the balance: Fixing Canada's economic immigration policies. Toronto: Maytree Foundation

Altbach, P. G., \& Knight, J. (2007). The internationalization of higher education: Motivations and realities. Journal of Studies in International Education, 11(3-4), 290-305. doi:10.1177/102831530730354

Arthur, N., \& Flynn, S. (2011). Career development influences of international students who pursue permanent immigration to Canada. International Journal for Educational and Vocational Guidance, 11(3), 221-237. Doi: 10.1007/s10775-011-9212-5

Anderson, T. (2015). Seeking internationalization: The state of Canadian higher education. The Canadian Journal of Higher Education, 45(4), 166

Asselin, M. E. (2003). Insider research: Issues to consider when doing qualitative research in your own setting. Journal for Nurses in Staff Development, 19(2), 99-103.

Atkinson R. \& Flint J. (2003). Snowball Sampling. In Lewis-Beck, M. S., Bryman, A., \& Liao, T. F. (Eds.). The SAGE encyclopedia of social science research methods SAGE.

Aupetit, S. D. (2006). The brain drain in Mexico-a subject for research. Or agenda? Globalisation, Societies and Education, 4(1), 103-120. doi:10.1080/14767720600555160

Basok, T., (2002) Tortillas and tomatoes: Transmigrant Mexican harvesters in Canada, Montreal: McGill-Queen's University Press.

Beine, M., Noël, R., \& Ragot, L. (2014). Determinants of the international mobility of students. Economics of Education Review, 41, 40-54 doi:10.1016/j.econedurev.2014.03.003

Binford, L. (2006) The Seasonal Agricultural Workers Program and Mexican Development. The Canadian Foundation for the Americas (FOCAL), Policy Paper 06-07, 1-14.

Binsardi, A., \& Ekwulugo, F. (2003). International marketing of British education: Research on the students' perception and the UK market penetration. Marketing Intelligence \& Planning, 21(5), 318-327. doi:10.1108/02634500310490265

Birks, M., \& Mills, J., Dr. (2015). Grounded theory: A practical guide Sage. Second Edition

Bhuyan, R., Vargas, A., \& Píntín-Perez, M. (2016). Fleeing domestic violence from a "safe" country?: Refugee determination for Mexican asylum-seekers in Canada. Refuge, 32(3), 95- 
107. Retrieved from

https://refuge.journals.yorku.ca/index.php/refuge/article/view/40373/36424

Bodycott, P. (2009). Choosing a higher education study abroad destination: What mainland Chinese parents and students rate as important. Journal of Research in International Education, 8(3), 349-373. doi:10.1177/1475240909345818

Bond, S., \& Canadian Bureau for International Education. (2007). Northern lights: International graduates of Canadian institutions and the national workforce Canadian Bureau for International Education.

Bragg, B., \& Wong, L. L. (2015). "Cancelled Dreams”: Family Reunification and Shifting Canadian Immigration Policy. Journal of Immigrant \& Refugee Studies, 14(1), 4665. doi:10.1080/15562948.2015.1011364

Brem, M. (2006). Migrant workers in Canada: A review of the Canadian Seasonal Agricultural Workers Program. Ottawa, ON: North-South Institute. doi:https://books.scholarsportal.info/en/read?id=/ ebooks/ebooks0/ gibson_cppc/2009-12$01 / 4 / 204614$

Calder, M. J., Richter, S., Mao, Y., Burns, K. K., Mogale, R. S., \& Danko, M. (2016). International students attending Canadian universities: Their experiences with housing, finances, and other issues. The Canadian Journal of Higher Education, 46(2), 92

Castles, S., Haas, H. de, \& Miller, M. J. (2014). The age of migration: international population movements in the modern world. Fifth edition. New York: Guilford Press.

Charmaz, K. (2006). Constructing grounded theory: A practical guide through qualitative analysis Sage

Chatterjee, S. (2015). Skills to build the nation: The ideology of 'Canadian experience' and nationalism in global knowledge regime. Ethnicities, 15(4), 544-567. doi: $10.1177 / 1468796815577702$

Chen, L. (2007). Choosing Canadian graduate schools from afar: East Asian students' perspectives. Higher Education, 54(5), 759-780. doi:10.1007/s10734-006-9022-8

Chen, J. M. (2017). Three levels of push-pull dynamics among Chinese international students' decision to study abroad in the Canadian context. Journal of International Students, 7(1), 113-135. doi:10.32674/jis.v7i1.248

CBIE. (2018, August). International Students in Canada (Rep.). doi:https://cbie.ca/wpcontent/uploads/2018/09/International-Students-in-Canada-ENG.pdf

Cudmore, G. (2005). Globalization, internationalization, and the recruitment of international students in higher education, and in the Ontario Colleges of Applied Arts 
and Technology. The Canadian Journal of Higher Education, 35(1), 37-60. Retrieved from https://eric.ed.gov/?id=EJ720728.

Dam, H., Chan, J., \& Wayland, S. (2018). Missed opportunity: International students in Canada face barriers to permanent residence. Journal of International Migration and Integration, 19(4), 891-903. doi:10.1007/s12134-018-0576-y

Felix, M. C. (2003). Los flujos migratorios de estudiantes mexicanos de posgrado hacia el extranjero. Revista De La Educación Superior,23(125), 68-85. Retrieved from https://biblat.unam.mx/es/revista/revista-de-la-educacion-superior/articulo/los-flujosmigratorios-de-estudiantes-mexicanos-de-posgrado-hacia-el-extranjero.

Gabriel, C. (2006). A question of skills: Gender migration policy and the global political economy. In Global regulation: Managing crises after the imperial turn (pp. 162-176). Palgrave Macmillan.

Gates-Gasse, E. (2010). “Two step” Immigration: Canada's new immigration system raises troubling issues. Retrieved April 20, 2016 from https://www.policyalternatives.ca/publications/monitor/two-step-immigration

Ge, L., Brown, D., \& Durst, D. (2019). Chinese international students' experiences in a Canadian university: Ethnographic inquiry with gender comparison. Journal of International Students, 9(2), 582-612. doi:10.32674/jis.v0i0.272

George, U. (2008). Mexican Migration to Canada: Case Study Report. Journal of Immigrant \& Refugee Studies, 6(3), 463-474. doi:10.1080/15362940802371945

Gérard, E, \& Maldonado, E. (2009). "Polos de saber" y "cadenas de saber": Impactos de la movilidad estudiantil en la estructuración del campo científico mexicano. Revista de la educación superior, 38(152), 49-62. Recuperado en 24 de julio de 2019, de http://www.scielo.org.mx/scielo.php?script=sci_arttext\&pid=S0185$27602009000400004 \& \operatorname{lng}=$ es\&tlng=en.

Government of Canada. (2014). Canada's International Education Strategy: Harnessing our knowledge to drive innovation and prosperity. Department of Foreign Affairs, Trade and Development. Retrieved from: http://international.gc.ca/global-markets-marchesmondiaux/assets/pdfs/overviewapercu-eng.pdf

Government of Canada (2018) Facts and Figures 2017 - Immigration Overview - Temporary Residents. Retrieved July 27, 2019, from https://open.canada.ca/data/en/dataset/2bf9f85620fe-4644-bf74-c8e45b3d94bd

Government of Canada. (2019a, June 27). Retrieved August 01, 2019, from http://www.cic.gc.ca/english/helpcentre/glossary.asp\#foreign_student 
Government of Canada. (2019b, March 26). Investing in Young Canadians. Retrieved July 27, 2019, from https:/www.budget.gc.ca/2019/docs/youth-jeunes/youth-jeunesen.html\#international-education-strategy

Guo, Y., \& Guo, S. (2017). Internationalization of Canadian higher education: Discrepancies between policies and international student experiences. Studies in Higher Education, 42(5), 851-868. doi:10.1080/03075079.2017.1293874

Harris, K. (2016, December 1). Mexican visa lift expected to cost Canada \$262M over a decade. $C B C$. Retrieved from https://www.cbc.ca/news/politics/mexico-visa-immigration-canadamccallum-1.3875483

Haug, S. (2008). Migration networks and migration decision-making. Journal of Ethnic and Migration Studies, 34(4), 585-605. doi:10.1080/13691830801961605

IRCC. (2017a, July 21). Get a Study Permit - Get the right documents. Retrieved from https://www.canada.ca/en/immigration-refugees-citizenship/services/studycanada/study-permit/prepare/get-documents.html\#doc3

IRCC. (2017b, June 28). Comprehensive Ranking System (CRS) Criteria - Express Entry. Retrieved from https://www.canada.ca/en/immigration-refugeescitizenship/services/immigrate-canada/express-entry/eligibility/criteria-comprehensiveranking-system/grid.html

Jiwani, Y. (2006) Discourses of Denial: Mediations of Race, Gender, and Violence. Vancouver: University of British Columbia Press.

Li, F., \& Qi, H. (2019). An investigation of push and pull motivations of Chinese tourism doctoral students studying overseas. Journal of Hospitality, Leisure, Sport \& Tourism Education, 24, 90-99. doi:10.1016/j.jhlste.2019.01.002

Li, X., \& Tierney, P. (2013). Internationalization in Canadian higher education: Experiences of international students in a master's Program/Internationalisation dans l'enseignement superior Canadien: Expériences d'étudiants internationaux dans un programme de maîtrise. Canadian and International Education, 42(2), 1.

López Ramírez, M. (2017). ¿En México o en el extranjero?: tipos de toma de decisión de estudiantes mexicanos sobre el lugar para realizar su doctorado. Sociológica (México), 32(90), 145-180. Recuperado en 24 de julio de 2019, de http://www.scielo.org.mx/scielo.php?script=sci_arttext\&pid=S018701732017000100145\&lng=es\&tlng=e

Lu, Y., \& Hou, F. (2015). International students who become permanent residents in Canada. Statistics Canada. Retrieved from https:/www150.statcan.gc.ca/n1/dailyquotidien/151210/dq151210c-eng.htm. 
María Cubillo, J., Sánchez, J., \& Cerviño, J. (2006). International students' decision-making process. International Journal of Educational Management, 20(2), 101-115. doi:10.1108/09513540610646091

Maringe, F., \& Carter, S. (2007). International students' motivations for studying in UK HE: Insights into the choice and decision making of African students. International Journal of Educational Management, 21(6), 459-475. doi:10.1108/09513540710780000

McMahon, M. E. (1992). Higher education in a world market. an historical look at the global context of international study. Higher Education, 24(4), 465-482. doi:10.1007/BF00137243

Martinez, M. D. (2018, January 18). Unos 26,000 jornaleros mexicanos trabajarán en el campo canadiense. El Economista. Retrieved from

https://www.eleconomista.com.mx/empresas/Unos-26000-jornaleros-mexicanos-trabajaranen-en-el-campo-canadiense--20180118-0032.html

Mavroudi, E., \& Warren, A. (2013). Highly skilled migration and the negotiation of immigration policy: Non-EEA postgraduate students and academic staff at English universities. Geoforum, 44, 261-270. doi:10.1016/j.geoforum.2012.08.008

Mazzarol, T., \& Soutar, G. N. (2002). "push-pull" factors influencing international student destination choice. International Journal of Educational Management, 16(2), 82-90. doi: $10.1108 / 0951354021041840$

McEwan, J., \& Teixeira, C. (2012). Doing their "home" work: A case study of university of British Columbia Okanagan student youth rental housing experiences in the city of Kelowna. BC Studies, (173), 123

Mueller, R. E. (2005). Mexican Immigrants and Temporary Residents in Canada: Current Knowledge and Future Research. Migraciones Internacionales, 3(1). Retrieved from http://www.scielo.org.mx/scielo.php?script=sci_arttext\&pid=S1665-89062005000100002

Knight, J. (2008). The role of cross-border education in the debate on education as a public good and private commodity." Journal of Asian Public Policy 1 (2): 174-87. doi:10.1080/17516230802094478.

Nunes, S., \& Arthur, N. (2013). International students' experiences of integrating into the workforce. Journal of Employment Counseling, 50(1), 34-45. doi:10.1002/j.21611920.2013.00023.x

Parra-Sandoval, M. C. (2014). La Movilidad de Estudiantes de Posgrado de Venezuela y México a Canadá: Un Estudio Exploratorio. Revista Latinoamericana de Educación Comparada, 5(5), 93-105. Retrieved from https://dialnet.unirioja.es/servlet/articulo?codigo=4766912.

Preibisch, K. \& Hermoso Santamaria, L. (2006) Engendering labour migration: The case of foreign workers in Canadian agriculture (pp. 107-130) in Tastsoglou, E. 
\& Dobrowolsky, A. (Eds.) Women, Migration and Citizenship: Making Local, National and Transnational Connections.

Preibisch, K., \& Encalada Grez, E. (2010). The other side of el otro lado: Mexican migrant women and labor flexibility in Canadian agriculture. Signs: Journal of Women in Culture and Society, 35(2), 289-316. doi:10.1086/605483

Rehaag Tobey, I. M. (2008). Una estancia de estudio en el extranjero: Experiencias en tres continentes. Revista De La Educación Superior, 37(147), 137-147.

Rodríguez Gómez, R. (2009). "Migración de personal altamente calificado de México a Estados Unidos: una exploración del fenómeno". Revista Electrónica de Investigación Educativa 11(2). Disponible en: $<\mathrm{http} / / /$ redie.uabc.mx/vol11no2/contenido-rodgo2.html $>$

Rotman, M., \& Marshall, K. (2016). 'Unsafe' and on the Margins: Canada's Response to Mexico's Mistreatment of Sexual Minorities and People Living with HIV (Rep.). Toronto: IHRP. Retrieved from https://ihrp.law.utoronto.ca/page/working-group-and-clinicreports/unsafe-and-margin

Sá, C. M., \& Sabzalieva, E. (2018). The politics of the great brain race: Public policy and international student recruitment in Australia, Canada, England and the USA. Higher Education, 75(2), 231-253. doi:10.1007/s10734-017-0133-1

Scott, C., S. Safdar, R. Desai Trilokekar, and A. El Masri. (2015). "International Students as "Ideal Immigrants" in Canada: A Disconnect Between Policy Makers' Assumptions and the Lived Experiences of International Students." Comparative and International Education/Éducation Comparée et Internationale 4 (3): Article 5.

Shanka, T., Quintal, V., \& Taylor, R. (2006). Factors influencing international students' choice of an education destination-A correspondence analysis. Journal of Marketing for Higher Education, 15(2), 31-46. doi:10.1300/J050v15n02_02

She, Q., \& Wotherspoon, T. (2013). International student mobility and highly skilled migration: A comparative study of Canada, the united states, and the United Kingdom. Springerplus, 2(1), 1-14. doi:10.1186/2193-1801-2-132

Sieglin, V., \& Zúñiga, M. (2010). "Brain drain" en México: Estudio de caso sobre expectativas de trabajo y disposición hacia la migración laboral en estudiantes de ingeniería y ciencias naturales. Perfiles Educativos, 32(128), 55-79

Statistics Canada. (2017). 2016 Census. Retrieved from https://www12.statcan.gc.ca/censusrecensement $/ 2016 / \mathrm{dppd} / \mathrm{prof} / \mathrm{details} /$ Page.cfm?Lang=E\&Geo1=PR\&Code1 $=35 \& G e o 2=\& \mathrm{C}$ ode $2=\&$ Data $=$ Count $\&$ SearchText $=$ Ontario $\&$ Sar

Statistics Canada. (2018). 37-10-0045-01 Canadian and international tuition fees by level of study. Retrieved from https://www150.statcan.gc.ca/t1/tbl1/en/tv.action?pid=3710004501 
Statistics Canada. (2019). Table 37-10-0086-01 Postsecondary enrolments, by status of student in Canada, country of citizenship and sex. Retrieved from

https://www150.statcan.gc.ca/t1/tbl1/en/cv.action?pid=3710008601

STPS (2018, December 5) Dirección General de Asuntos Jurídicos. Unidad de Transparencia. Oficio No. STPS/UT/1016/18 Clasificación: Información Pública, Folio: 0001400101618

Todaro, M.P. (1976) Internal migration in developing countries: A survey. Geneva: International Labor Office.

Tremblay, K. (2005). Academic mobility and immigration. Journal of Studies in International Education, 9(3), 196-228. doi:10.1177/1028315305277618

Villegas, P. E. (2013). Assembling a visa requirement against the Mexican 'wave': Migrant illegalization, policy and affective 'crises' in Canada. Ethnic and Racial Studies, 36(12), 2200-2219. doi:10.1080/01419870.2012.705009

Wang, C. (2018). Immigration gridlock: Assessing whether Canada's express entry is an effective immigration system for international students' transition into permanent residency? Journal of International Students, 8(2), 1059-1078. doi: $10.5281 /$ zenodo. 1250408

Wilkins, S., Balakrishnan, M. S., \& Huisman, J. (2012). Student choice in higher education: Motivations for choosing to study at an international branch campus. Journal of Studies in International Education, 16, 413-433. https://doi.org/10.1177/1028315311429002.

Wintre, M. G., Kandasamy, A. R., Chavoshi, S., \& Wright, L. (2015). Are international undergraduate students emerging adults? motivations for studying abroad. Emerging Adulthood, 3(4), 255-264. doi:10.1177/2167696815571665

Yang, Y., Volet, S., \& Mansfield, C. (2018). Motivations and influences in Chinese international doctoral students' decision for STEM study abroad. Educational Studies, 44(3), 264-278. doi:10.1080/03055698.2017.1347498

Young, J. E. (2018). The Mexico-Canada border: Extraterritorial border control and the production of economic refugees. International Journal of Migration and Border Studies, 4(1/2), 35-50. doi:10.1504/ijmbs.2018.10012233

Zhang, Z., \& Zhou, G. (2010), Understanding Chinese international students at a Canadian university: Perspectives, expectations, and experiences, Canadian and International Education, 39(3), 43-58

Zhou, G., \& Zhang, Z. (2014). A study of the first year international students at a Canadian university: Challenges and experiences with social Integration/Une étude des étudiants internationaux de première année dans une université canadienne : Défis et expériences avec l'intégration sociale. Canadian and International Education, 43(2), 1 
Zhukovskyi, V., \& Simak, K. (2015). The prerequisites to Ukrainian students participation in study abroad programs at the Canadian universities and colleges. Comparative Professional Pedagogy, 5(2), 39-46. doi:10.1515/rpp-2015-0038 